\title{
Discursive Strategies of Contemporary Subcultures in the Global Context
}

\author{
CHEN Min \\ China Youth University of Political Studies, Beijing, China
}

\begin{abstract}
Since the 20th century, the subculture, once a marginal cultural phenomenon, has been transformed into a global post-subculture. In this process, subcultural groups have undergone profound changes in multiple aspects. Hybridity, openness, and dissolution of depth become the keywords to understand youth subcultures. This paper is attempted to explore its discursive changes in comptemporary subcultures. By describing and interpreting the most popular subcultural discourse-hip-hop discourse, it is found that counter language often used in the subcultural discourse has been weakened and new strategies, such as code switching and semiotic games arise. The paper argues that with the transition of discursive strategies, subcultural groups attempt to weave the network of the global subcultures and create an interactive discursive space for global youth.
\end{abstract}

Keywords: subcultures, globalization, discursive strategies

\section{Introduction}

The late 1980s witnessed accelerated circulation of commodities, capital, technologies, and information among countries and the trend of globalization. Globalization fueled the cultural communication and promoted the development of cultures in different countries. Subculture, active in the forefront of cultures, is no exception. It underwent the transformation from a regional marginal-culture to a global cultural phenomenon which led to a series of changes in the discourse of contemporary subcultures. These changes have refreshed the outlook of youth subculture, formed the bonds among the global youth groups for communication and created an interactive discursive space for global youth.

\section{Subcultures in the Era of Globalization}

Since the 1950s, along with the economic recovery of the US and Britain after the World War II, the urbanization process, and the rise of consumerism, cultural movements on both sides of the Atlantic have sprung up, among which the youth subculture is the most active one. The subcultural groups distinguished themselves by unique clothes, music taste, and lifestyles that are different from mainstream culture, and had a significant impact on the youth from middle and lower classes. Teddy Boys, The Mods, Skinhead, and punk became the cultural symbols throughout the 50s to 70s; Hippies, Yuppies, and Hip-Hop, emerged in the 60s and 70s of America, were a unique scene in the Western cultural wave of the 20th century and were quite popular at the time.

Since the 1980s, with the rise of modern media, the development of international cultural industry, and the

CHEN Min, lecturer, master, The Department of English Language and Literature, China Youth University of Political Studies. 
popularization of the Internet, the social and international space for the development of subcultures in different countries expanded tremendously, and the subcultures spread beyond the traditional boundaries of regions, classes, and countries and embraced the feature of openness. Influenced by integration and interaction of multi-cultures, the cutting-edge subcultures are also featured by hybridity. For instance, Muslim rock in Africa, Asian rap in London, and American cartoon in Germany all reflect the hybridity of youth subcultures under the multi-cultural influence. Meanwhile, the development of transnational cultural industry drives the consumption of youth-targeted subcultural commodities and further complicates the relations between business and youth subculture. On the one hand, commerce facilitates the international communication of subcultures and even creates various subcultural tribes. On the other hand, it accelerates the deconstruction of rebellion of subculture against the mainstream culture and dissolves its depth, which has become the distinctive features of subculture in the era of globalization. Openness, hybridity, and dissolution of depth endow subculture with apparent features of globalization.

The transformation of subcultures draws the attention of the scholars who study the Western subcultures. They acclaimed for the upcoming of the "post-subculture era" and initiated a heated debate on whether it posed challenges to the subculture theories. Critics on subcultures, such as Muggleton (2004) and Bennet (2004), believe that as the society develops, the subculture theories that focus on rebellion and the influence of social classes and division of labor on subcultures are no longer applicable to the contemporary subcultures in the global waves, and the contemporary youth subcultures put more emphasis on the choices and construction of the way young people live and consume. However, the supporters of subculture theories, represented by Bradman, hold that the social class and other social inequalities still have significant implications for youth subculture (MA, 2010). Martina Bose (2003) indicated specifically that

The features of subculture, which is the center of early contemporary culture research, and the core concepts of race, social class, social isolation and power relations are still the basis on which we understand the lifestyles and cultural selection of the youth. (p. 178)

No matter how profound the transformation of subcultures has been, it is beyond all doubt that the subcultures and subcultural groups have changed in multiple aspects in the globalization process. Among others, one of the most significant changes finds itself in the transformation of the subculture discourse.

\section{The Study of Discourse From Cultural Perspective}

In linguistics, discourse is "a language unit larger than a sentence in written or oral expression" (Austin, 2002, p. 1). Most of the daily life is composed of verbal communication and discourses, which voiced the social life. In the 1960s, the research on discourse became an interdisciplinary study that involved literary studies, sociology, politics, communication science, etc., and the research shifted its focus from the language itself to the interactive relations between language and power, social order and ideologies. According to Foucault, discourse is able to effectively construct the society, adjust and control knowledge, social relations, and institutions, and construct social identities and behaviors (HUANG \& XU, 2006). On the other hand, social linguists contend that discourse is one of the factors influential in social life and has dialectical relations with the other factors (Fairclough, 2003). This language use is a discursive practice capable of constructing certain knowledge as well maintaining unequal power relations. Therefore, the discourse is a language practice of social ideologies in a 
certain social and historical context.

Since the 1990s, the research on discourse has extended itself to cultural studies. Discourse has been introduced to the cultural research as a new research methodology and theory due to two main reasons. One is that discourse is the carrier of culture that includes large research data of cultures, and the other is that discourse itself is a part of culture. It acts as the barometer of cultural change and takes more control of people's life. Chinese researchers have discussed and studied different cultural forms, such as minority cultures, regional cultures, and popular culture from the discourse perspective. For instance, ZHAO Xiao-song (2001) reviewed pluralistic discourse of Miao culture with the contemporary discourse theory and JIA Huan-jie (2012) conducted a case analysis of the media discourse of the Heluo culture. Although Chinese scholars have researched culture and discourse for two decades, the number of discourse research on youth subcultures and groups is quite small, and the discourse research on youth subculture in a global context is even more scarce. This paper attempts to analyze the changes in one aspect of the subcultural discourse, namely the discursive strategies and explore the features of subculture in the era of globalization.

\section{The Discursive Strategies of Contemporary Youth Subcultures}

In its early days, counter language, metaphor, and the first personal narrative point of view are the major discursive strategies for the early youth subcultures. They constructed the distinctive subcultural identity that deviated from mainstream culture and reaffirmed the subcultural values. In the global era, however, the use of counter language declines, code switching and symbolic games become the emerging new discursive strategies of contemporary youth cultural groups.

In the last century when the youth subcultures were only a regional and marginal culture, counter language is a commonly used discursive strategies of youth subcultural groups. Counter language is "a language form with lexical features different from mainstream standard language, and more specifically, a discursive practice that counter-cultural group uses to revolt, resist and disturb dominate mainstream culture and separate itself from the mainstream" (DING, 2010, p. 77). Take the hip-hop language for example. It originated from the African-American vernacular and differed from the standard mainstream English in terms of pronunciation, grammar, and vocabulary. Therefore, it was considered non-standard English. The hip-hoppers used the counter language to construct a hip-hop cultural world distinct from mainstream culture. In the meantime, hip-hop language used to be featured by metaphor which was used extensively to isolate the hip-hop community from the outside world and establish the identity of subcultural members. In this way, it reflected the closure of subcultural groups. For example, metaphors were frequently used in hip-hop language to refer to violence, drug, and money encountered by urban black youth. In terms of narrative strategies, hip-hop singers often expressed personal feelings or told personal experiences from the first personal point of view, the goal of which was to build a unique subcultural identity of the hip-hop members and expressed their rebellion against mainstream culture.

In the process in which subculture spreads to the world, the counter language which used to be the main linguistic feature of subcultures gradually declines. After researching 41 songs of eight American hip-hop singers, the American scholar Edwards (2006) found that the grammar of standard English was used more often than that of the African-American English by contemporary hip-hop singers in their songs and in this way, the discourses these singer produce get closer to standard English. As to Chinese hip-hop music, it was found that Chinese 
hip-hop songs mainly use standard Chinese as its lingua franca in terms of vocabulary, grammar, and pronunciation. Meanwhile, the language is cleaner, since the counter language in Chinese hip-hop music is much less frequently used than its American counterparts. The representative of Northern School, KungFu Pop highly praised their creed of "do healthy things, speak clean language", and the typical Southern School music group Hi-Bomb claims “we don’t curse!” Taiwan singer Wilber Pan even proclaimed not to sing hip-hop with vulgar words. The rejection of counter language, on one hand, can overcome the obstacles of language differences when subculture spread across regions, and on the other hand, it also indicates that youth subcultures, driven by commercialization, signals reconciliation and compromise with mainstream culture.

Besides the rejection of counter language, in the era of globalization, the subcultural groups have adopted new discursive strategies to build a bond among subcultural youth groups from different regions and cultures. One of the most important strategies is code switching. It is the use of two or more languages in one discourse process to perform the social function of identity construction.

Take hip-hop culture as an example. In its early years, English acted as its carrier and standard language used by its group members, yet as its groups diversified, the mixing of English and local languages becomes the discourse strategy commonly used by hip-hop cultural groups in various countries. No matter in European countries like Germany, France, and Sweden or in Japan, Korea, and Vietnam, more and more local hip-hop singers began to use local dialects to express the values and desires of the hip-hop groups, trying to get closer the local subcultural groups and reveal their local identities.

In addition, the use of a foreign language has the aesthetic function of defamilarization, which acts as an artistic method that extends the time of aesthetic appreciation and enhances the aesthetic effect by increasing the difficulties in understadning a certain kind of art form. For instance, in the lyrics of a song entitled "Life's Struggle”, which is written by Taiwan hip-hop star ZHAO Yue-ting (2003), the use of code switching can be identified:

Original version:

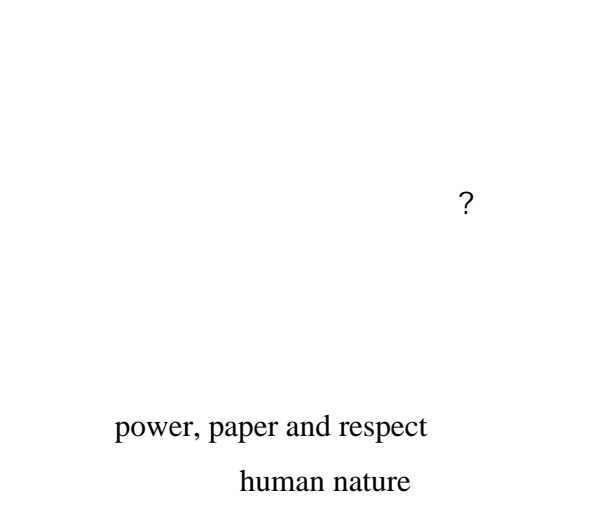

Translated version:

I open my eyes and step into this world Mama gave me life but now I'm on my own It terrifies me and I see everyone wearing a mask When I look back, I wonder how life can go on in that way I keep on smoking till my lung turns black 
Just like the society polluted by human hearts

I carry the destiny cross on my shoulder

Longing for power, paper and respect

I guess that is human nature

In the rapid rhythm of rap, the singer uses complicated Chinese and simple English to pour out his confusion about life and his sorrows. For one thing, the use of English words "power", "paper”, and "respect” makes it more difficult to appreciate the song for Chinese youth who are unfamiliar with these words. In this way, it not only intensifies the listeners' aesthetic experience, but also gives them a sense of international fashion by indicating the relation of their aesthetic experience with global hip-hop culture (indicating that hip-hop music originates from abroad). For another, the use of local language can link itself with local hip-hop culture, attracting the local youth group and gaining their recognition.

Moreover, the use of English, which originated from hip-hop culture discloses the relation between the singer and global hip-hop culture and the singer's identity as a member of global hip-hop culture. The combination of the two languages indicates that the singer has excellent command over both global and local hip-hop language, and helps establish the singer's dual identity of both global and local hip-hop cultural group members, enabling the singer to elevate his status and better his image among youth listeners.

The symbolic game is another important strategy of contemporary subcultural discourse in the globalization process. The globalized society is highly symbolic. In current society, everyone and everything must go through symbolization governed by the rule of common symbolic logic. In a global context, the discursive system not only conveys thoughts and expresses ideas, but also evolves as a symbolic game traveling through cultures. As the subcultures spread to different parts of the world, some subcultural slang words remain alive due to extensive use and become the symbol of subcultural groups. For example, in hip-hop language, some slang words like "nigga”, “yo”, "peace”, "bling bling”, and "na mean” are well known to hip-hop groups as the hip-hop culture is globalized. The word "nigga” once was a contemptuous term for black people, but in the global transmitting process it gradually evolves into a name for black youth who are courageous, fearless, and free from common conventions, and becomes the cultural symbol for the hip-hop group. After researching on the comments of about 100,000 words on a hip-hop website, German scholar Fagersten (2006) discovered that hip-hop slang and taboo words that have specific meanings, e.g., battle, flow, and nigga, are used repeatedly and extensively, therefore turning into the linguistic means of indicating one's identity as a hip-hop group member. In addition to the use of linguistic symbols to indicate identity in group names and activities, subcultural groups also utilize linguistic symbols in youth fashion featuring personal styles. When conducting a research on the hip-hop fashion, Morgado found that some typical hip-hop slang words remain the important factors of hip-hop fashion (Morgado, 2007). Therefore, hip-hop language and symbolic game in subcultural groups, which act as cultural symbols, can be largely found in hip-hop music, on-line communication, and fashion.

The symbolic subcultural discourse applied to various fields penetrates the daily practices of subcultures and establishes an internal identity of hip-hop groups in regions and nations all over the world.

\section{Conclusion}

In the globalization wave, subcultural features that built on the traditional boundaries of nation, region, and 
social class are beginning to turn obscure, and take a hybridized, complex, and highly transformed appearance. Traditional subcultural discursive strategies such as counter language are intentionally weakened by youth groups. Instead, with the emergence of new discursive strategies such as code switching and symbolic games, subcultural groups reconcile their rebellious posture, develop an bond for global youth groups to communicate and establish the interactive space for global youth. The transformation of youth subcultural discursive strategies evidently reveals the youth groups' deliberate extension of discursive space driven by global media and the commercial culture on the basis of multi-cultural communication. As a result, the style of youth subculture and the communication means of the subcultural groups have underwent profound changes, and subcultures gain more momentum from the globalization as it heads for the new age.

\section{References}

Austin, J. (2002). How to do things with words. Beijing: Beijing Foreign Language Teaching and Research Press.

Bennett, A., \& Kahn-Harris, K. (2004). After subculture: Critical studies in contemporary youth culture. London: Palgrave.

Bose, M. (2003). Race and class in the post industrial economy. In D. Muggleton \& R. Weinzierl (Eds.), The post subcultural reader. Oxford: Berg.

DING, J. X. (2010). 作为社会符号的“反语言” —“边缘话语与社会” 系列研究之一 (Anti-language as sociosemiotic: Social interpretation of marginalized discourse). 外语学刊, (2), 76-83.

Edwards, W. (2006). The sociolinguistics of rap lyrics. In H. S. Alim, Roc the Mic Right: The language of hip hop culture. NY: Routledge.

Fagersten, K. B. (2006). A corpus approach to discursive construction of hip hop identity. Retrieved from www.du.se/PageFiles /3021/Kristy\%20Beers.doc

Fairclough, N. (2003). Analysing discourse: Textual analysis for social research. London and New York: Routledge.

HUANG, G. W., \& XU, J. (2006). 语篇分析与话语分析 (Texual analysis and discourse analysis). 外语与外语教学, (10), 1-6.

JIA, H. J. (2012). 河洛文化话语向度研究 (The study of Heluo cultural discourse). 新闻与传播研究, (3), 17-18.

MA, Z. H. (2010). 西方后亚文化研究的理论走向 (The theoretical trends in post subcultural studies). 国外社会科学, (1), 137-142.

Morgado, M. (2007). The semiotics of extraordinary dress: A structural analysis and interpretation of hip hop style. Clothing and Textiles Research, (25), 131.

Muggleton, D., \& Weinzierl, R. (2004). The post subcultures reader. Oxford: Berg.

ZHAO, X. S. (2001). 多元文化中的苗族话语研究 (Study of Miao’s discourse in multiple cultures). 贵州民族研究, (3), 44-51. 